\title{
UPAYA MENINGKATKAN HASIL BELAJAR KONSEP SISTEM KOORDINASI DAN ALAT INDERA MELALUI METODE PERMAINAN WHO WANTS TO BE A SMART STUDENT PADA SISWA KELAS IX F SMP NEGERI 1 BANDUNGAN TAHUN 2013/2014
}

\author{
Eni Riptyawati
}

\begin{abstract}
Abstrak
Hasil refleksi awal pembelajaran IPA menunjukkan pencapaian ketuntasan secara klasikal rendah yaitu 53,8\%. Rendahnya hasil belajar siswa karena guru belum memanfaatkan metode yang kreatif sehingga pelajaran menjadi membosankan. Rendahnya hasil belajar ini memacu guru untuk meningkatkan kualitas proses pembelajaran dengan menggunakan metode quis Who Wants to be A Smart Student. Tujuan penelitian ini untuk meningkatkan hasil belajar konsep Sistem Koordinasi dan Alat Indera melalui metode permainan Who Wants to be A Smart Student. Penelitian ini dilakukan pada siswa kelas IX F SMP Negeri 1 Bandungan Tahun Pelajaran 2013/2014. Penelitian ini menggunakan 2 siklus, setiap siklus terdiri dari 4 tahap yaitu perencanaan, pelaksanaan tindakan, observasi dan refleksi. Pembelajaran model permainan Who Wants to be A Smart Student berhasil apabila standar kompetensi yang diharapkan tercapai. Indikatornya adalah apabila $85 \%$ siswa dapat mencapai hasil belajar dengan SKBM 70 \%. Hasil penelitian menunjukkan bahwa hasil belajar siswa mengalami peningkatan dari siklus 1 hingga siklus 2.Peningkatan tersebut meliputi rerata hasil belajar dari 73,4 pada siklus 1 menjadi 81,3 pada siklus 2, sehingga terjadi kenaikan sebesar 7,9 poin. Ketuntasan belajara secara klasikal juga mengalami kenaikan dari $65,4 \%$ pada siklus 1 menjadi $88,5 \%$ pada siklus 2, sehingga mengalami kenaikan sebesar 23,1\%. Aktifitas siswa mengalami kenaikan sebesar $25 \%$ dari siklus 1 sebesar $66,7 \%$ menjadi $87,5 \%$ pada siklus 2 .
\end{abstract}


Berdasarkan hasil analis data di atas dapat disimpulkan bahwa metode pembelajaran dengan menggunakan permainan Who Wants to be A Smart Student dapat meningkatkan hasil belajar pada siswa kelas IX F SMP Negeri 1 Bandungan Tahun Pelajaran 2013/2014. Meningkatnya hasil belajar ini dibuktikan dengan perolehan hasil belajar siswa yang telah memenuhi standar ketuntasan belajar minimal yang telah ditetapkan. Penggunaan metode permainan Who Wants to be A Smart Student merupakan salah satu metode alternatif bagi guru dalam pembelajaran yang disarankan untuk digunakan pada kompetensi dasar mendeskripsikan sistem koordinasi dan alat indera dan hubungannya dengan kesehatan.

Kata Kunci : Hasil Belajar dan Permainan Who Wants to be A Smart Student

\section{PENDAHULUAN}

Pelajaran IPA merupakan salah satu pelajaran yang dapat meningkatkan kualitas pendidikan, namun hasil belajar IPA di sekolah dasar dan menengah belum menunjukkan hasil yang menggembirakan. Salah satu indikator rendahnya hasil belajar IPA pada pendidikan dasar dan menengah adalah masih rendahnya daya serap siswa terhadap materi pelajaran. Hasil penelitian yang dilakukan melalui Programme for International Student Assessment (PISA) yang dilakukan setiap tiga tahun sekali. Pada tahun 2009 Indonesia menempati ranking 60 dari 65 negara peserta untuk kemampuan Matematika dan kemampuan Sains (PISA, 2009).

Kondisi awal siswa kelas IX F SMP Negeri 1 Bandungan, jika dilihat dari segi prestasi akademik masih kurang di bandingkan dengan kelas yang lainnya, sehingga apabila diberi materi, masih banyak siswa yang kurang memahami materi yang disampaikan. Siswa tidak menunjukkan aktivitas selama proses pembelajaran. Akibatnya lebih dari $60 \%$ siswa kurang aktif dalam pembelajaran seperti kurang berani bertanya. Hasil belajar siswa pun lebih dari 40 \% belum mencapai SKBM yaitu $75 \%$.

Berdasarkan pada kenyataan tersebut untuk meningkatkan ha- 
sil belajar IPA, maka siswa harus dirangsang untuk berperan aktif baik secara individual atapun kelompok. Model belajar dengan pengalaman sangat berarti dalam pendidikan siswa, terutama bagi anak yang mempunyai kesulitan belajar.

Salah satu cara agar siswa dapat mengatasi kesulitan dalam memahami materi, siswa harus dilibatkan secara langsung dalam pembelajaran. Guru harus menciptakan suasana belajar yang menyenangkan dan tidak membosankan. Model pembelajaran yang dapat menjadikan siswa merasa terlibat secara langsung adalah melalui permainan. Permainan dapat menjadi pilihan guru untuk menarik perhatian siswa. Siswa merasa ditantang untuk menjawab pertanyaan - pertanyaan yang diajukan guru. Dengan demikian siswa akan merasa senang dan terlibat langsung dalam pembelajaran. Secara tidak disadari siswa akan belajar dengan sendirinya. Dominock \& Clark (dalam Hamdani, 2010: 125) mengatakan bahwa belajar dengan permainan lebih memungkinkan anak mengembangkan konsep yang didasarkan pada klasifikasi dan mengkontruksi kategori melalui tindakan mereka sendiri.

Untuk mencapai harapan tersebut di atas, peneliti berupaya menggunakan metode yang tepat untuk menyampaikan materi pelajaran pada siswa. Penggunaan metode permainan Who Wants to be A Smart Student diharapkan dapat membantu merangsang siswa untuk ikut terlibat dalam proses belajar, sehingga diharapkan siswa dapat memahami materi sistem koordinasi dan alat indera dengan lebih baik.

Berdasarkan uraian di atas perlu penelitian untuk mengetahui apakah model pembelajaran permainan Who Wants to be A Smart Student dapat meningkatkan hasil belajar siswa kelas IX F pada konsep sistem koordinasi dan alat indera manusia di SMP Negeri 1 Bandungan Tahun 2013/2014, dan apakah model pembelajaran permainan Who Wants to be A Smart Student dapat meningkatkan aktivitas belajar siswa kelas IX F SMP Negeri 1 Bandungan Tahun 2013/2014. 


\section{KERANGKA TEORITIS}

\section{Hakekat Belajar}

Pada hakikatnya belajar dilakukan oleh siapa saja, baik anak anak maupun manusia dewasa. Pada kenyataannya ada kewajiban bagi manusia dewasa atau orang-orang yang mempunyai kompetensi lebih dahulu agar menyediakan ruang, waktu dan kondisi agar terjadi proses belajar pada anak. Dalam hal ini proses belajar diharapkan terjadi secara optimal pada siswa melalui cara-cara yang dirancang dan difasilitasi oleh sekolah. Dengan demikian diperlukan kegiatan pembelajaran yang harus disiapkan oleh seorang guru.

Belajar adalah suatu proses usaha yang dilakukan seseorang untuk memperoleh perubahan tingkah laku yang baru secara keseluruhan, sebagai hasil pengalamannya sendiri dalam interaksi dengan lingkungannya,menurut Slameto (dalam Hamdani, 2011: 20).

\section{Hasil Belajar}

Hasil belajar adalah kemampuan yang dimiliki siswa setelah ia menerima pengalaman belajarnya. Hasil belajar merupakan perilaku yang diperoleh pembelajar setelah mengalami aktivitas belajar. Perolehan aspek-aspek perubahan perilaku bergantung pada apa yang dipelajari oleh siswa. Oleh karena itu, apabila siswa mempelajari pengetahuan tentang konsep, perubahan perilaku yang diperoleh berupa penguasaan konsep. Dalam pembelajaran, perubahan perilaku yang harus dicapai oleh siswa setelah aktivitas belajar dirumuskan dalam tujuan pembelajaran (Anni, 2004: 4).

\section{Metode Pembelajaran dengan Permainan}

Metode pembelajaran Who Wants to be A Smart Students merupakan metode pembelajaran berupa permainan yang digunakan oleh peneliti sebagai upaya untuk meningkatkan hasil belajar IPA konsep Sistem Koordinasi dan Alat Indera Manusia. Metode ini merupakan bagian dari metode pembelajaran Team Games Tournaments (TGT) yang sudah dimodifikasi oleh peneliti. Nur \& Wikandari (dalam Trianto, 2011: 49) menjelaskan bahwa Teams games tournament (TGT) telah digunakan dalam berbagai macam mata pe- 
lajaran, dan paling cocok digunakan untuk mengajar tujuan pembelajaranyang dirumuskan dengan tajam dengan satu jawaban benar, seperti perhitungan dan penerapan berciri matematika, dan faktafakta serta konsep IPA. Dominock \& Clark (dalam Hamdani, 2010: 125) mengatakan bahwa belajar dengan permainan lebih memungkinkan anak mengembangkan konsep yang didasarkan pada klasifikasi dan mengkontruksi kategori melalui tindakan mereka sendiri.

\section{Kerangka Berpikir}

Metode permainan who wants to be a smart student diharapkan dapat meningkatkan hasil belajar IPA konsep sistem koordinasi dan alat indera. Peneliti menggunakan metode ini atas pemikiran bahwa belajar dengan suasana yang menyenangkan akan dapat meningkatkan aktifitas siswa dalam mengikuti pelajaran. Siswa akan merasa ikut terlibat dalam pembelajaran, siswa yang semula tidak aktif akan merasa tertantang untuk menjawab setiap pertanyaan yang diajukan dalam quis. Siswa yang semula kurang perhatian, diharapkan dapat tertarik dengan permainan ini.

Pada awal pembelajaran guru menyampaikan materi dalam penyajian kelas, dilakukan dengan pengajaran langsung atau dengan ceramah, diskusi yang dipimpin guru. Pada saat penyajian kelas ini , siswa harus benar-benar memperhatikan dan memahami materi yang diberikan guru, karena akan membantu siswa bekerja lebih baik pada saat kerja kelompok dan pada saat permainan karena skor permainan akan menentukan skor individu dan kelompok. Permainan terdiri atas pertanyaan-pertanyaan yang dirancang untuk menguji pengetahuan yang didapat siswa dari penyajian kelas dan belajar kelompok. Siswa yang menjawab benar pertanyaan itu akan mendapatkan skor. Dengan demikian siswa akan terlibat secara aktif dalam pembelajaran dan diharapkan dapat meningkatkan hasil belajar dan aktivitas siswa kelas IX F SMP N 1 Bandungan Tahun 2013/2014.

\section{Hipotesis Tindakan}

Hipotesis penelitian adalah melalui metode permainan Who Wants to be A Smart Student dapat meningkatkan hasil belajar siswa 
kelas IX F pada konsep Sistem Koordinasi dan Alat Indera di SMP Negeri 1 Bandungan tahun 2013/2014.

\section{Metode Penelitian}

Tempat penelitian dilakukan di kelas IX F SMP Negeri 1 Bandungan, Jimbaran, kecamatan Bandungan kabupaten Semarang. Waktu penelitian dilakukan mulai bulan Juli sampai bulan November 2013. Diawali dengan penyusunan proposal dan instrumen pada bulan Juli sampai Agustus 2013. Pelaksanaan siklus 1 pada minggu ke II bulan September 2013. Pelaksanaan siklus 2 pada minggu ke III bulan September 2013. Penyusunan laporan penelitian minggu I bulan Oktober sampai minggu ke IV bulan November 2013.

Subjek penelitian adalah siswa kelas IX F SMP Negeri 1 Bandungan, semester I tahun pelajaran 2013/2014. Sumber data dalam penelitian ini adalah guru dan siswa kelas IX F SMP Negeri 1 Bandungan tahun 2013/2014 yang berjumlah 26 siswa, terdiri dari 14 laki-laki dan 12 perempuan. Jenis data yang digunakan dalam penelitian ini adalah: (1) Hasil belajar siswa dalam pembelajaran IPA dilakukan melalui ulangan harian; (2) Aktivitas belajar siswa dalam pembelajaran IPA dilakukan melalui lembar observasi.

Penelitian ini menggunakan 2 siklus, setiap siklus terdiri dari 4 tahap yaitu perencanaan, pelaksanaan tindakan, observasi dan refleksi. Pada tahap perencanaan yang dilaksanakan adalah: (1) Guru menugaskan pada siswa untuk mempelajari materi quis; (2) menyusun rencana pelaksanaan pembelajaran (RPP) dengan materi sistem koordinasi dan alat indera manusia; (3) merencanakan pembelajaran dengan metode permainan who wants to be a smart student; (4) merancang instrumen pengamatan; (5) membagi kelompok secara heterogen berdasarkan kemampuan siswa menjadi 5 kelompok; (6) menyusun pertanyaan yang akan digunakan dalam quis.

Tahap pelaksanaan peneliti melaksanakan pembelajaran yang dimulai dengan: (1) Pembukaan dengan menyampaikan tujuan pembelajaran dan memotivasi siswa agar aktif dalam permaian quis who wants to be a smart student; (2) inti pelajaran yang berisi kegiatan berupa: Guru menyampaikan garis besar materi yang akan dijadikan pertanyaan pada permainan, siswa secara berkelompok mem- 
perhatikan materi dari guru dan mendiskusikan materi permainan tersebut, guru menawarkan kepada kelompok, siapa yang mau duduk di kursi panas terlebih dahulu untuk menjawab pertanyaan atau dengan cara diundi. Siswa yang duduk di kursi panas kemudian disebut dengan smart student. Guru memberikan point pada siswa yang berani maju sebagai wujud apresiasi guru kepada siswa. Setiap smart student akan mendapatkan 7 pertanyaan, masing-masing pertanyaan diberi batasan waktu selama 1 menit. Pertanyaan yang dapat dijawab dengan benar akan mendapatkan point 10, sedangkan peserta yang lainnya tetap menjawab pertanyaan dari guru di buku catatan dan akan dikumpulkan setelah permainan selesai. Hal ini untuk menghindari keributan ketika permainan berlangsung. Apabila smart student tidak dapat menjawab pertanyaan, maka akan diberi kesempatan untuk memilih dua bantuan yaitu phone a friend yaitu seakan-akan bercakap-cakap ditelepon dan bertanya kepada teman satu kelompok atau audiens yaitu smart student dapat bertanya kepada semua peserta/kelompok lain. Bantuan ini hanya berlaku untuk satu kali kesempatan saja. Apabila bantuan sudah habis, smart student harus menjawab pertanyaan sendiri dan jika salah harus turun dari kursi panas. Apabila menggunakan bantuan phone a friend, teman satu kelompok yang ditunjuk bisa menjawab maka smart student dapat terus maju dengan konsekuennya point menjadi milik temannya, tapi apabila tidak dapat menjawab maka smart student harus turun dari kursi panas dan diganti dengan smart student yang lain lagi dalam satu kelompok. Apabila menggunakan bantuan audiens, jika pertanyaan dapat dijawab oleh audiens/kelompok lain, maka smart student turun diganti dengan audien yang menjawab benar. Apabila audien tidak ada yang dapat menjawab maka smart student tetap maju, guru dapat memberikan jawaban. Kelompok yang dapat menyelesaikan semua pertanyaan dan mendapatkan point terbanyak akan menjadi pemenang dalam permainan ini, dan siswa yang mendapatkan point terbanyak dinobatkan sebagai smart student; (3) Penutup, Guru mengumumkan kelompok yang memenangkan permainan dan siswa yang dinobatkan sebagai smart student. Kemudian guru bersama siswa menyimpulkan kembali jawaban pertanyaan yang ditanyakan dalam 
permainan.

Tahap observasi merupakan pengumpulan data yang bersifat trianggulasi yaitu data berasal dari siswa, guru dan kolaborator. Jenis data terdiri data kuantitatif dan kualitatif. Alat pengumpul data berupa tes tertulis untuk mengetahui hasil kognitif siswa dan lembar observasi untuk mengetahui perubahan aktivitas siswa selama pembelajaran dengan metode permainan who wants to be a smart student.

Tahap terakhir adalah refleksi, data yang diperoleh dari hasil observasi selama proses pembelajaran dilakukan analisa dan dilakukan refleksi sebagai bahan penyusun rencana tindakan pada siklus berikutnya. Sedangkan teknik pengumpul data dilakukan melalui tes tertulis dan lembar observasi. Alat pengumpul data diperoleh dari dokumen daftar nilai hasil ulangan harian pada materi Sistem Koordinasi dan Alat Indera pada Manusia serta data pengamatan aktivitas siswa. Data yang didapat dianalisis secara kuantitatif dan kualitatif. Secara kuantitatif data dianalisis dengan teknik deskriptif komparatif, yaitu membandingkan hasil evaluasi pada kondisi awal, siklus 1, dan siklus 2 dengan berpatokan pada indikator kerja yang sudah ditentukan yaitu nilai 75 sebagai batas ketuntasan minimal. Secara kualitatif data dianalisis dengan teknik deskriptif kualitatif, yaitu dengan melihat data yang diperoleh melalui observasi setiap siklus.

\section{Indikator Keberhasilan}

Pembelajaran model permainan Who Wants to be A Smart Student berhasil apabila standar kompetensi yang diharapkan tercapai. Indikatornya adalah apabila $85 \%$ siswa dapat mencapai hasil belajar dengan SKBM 75 \%.

\section{HASIL PENELITIAN DAN PEMBAHASAN Hasil Penelitian}

Siklus 1 dilaksanakan dalam 2 kali pertemuan. Pertemuan pertama pada hari Selasa, 10 September 2013 dan pertemuan kedua pada hari Rabu, 11 September 2013. Siklus 2 dilaksanakan dalam 1 kali pertemuan pada hari Selasa, 17 September 2013. 


\section{Siklus 1}

\section{Hasil Belajar Siswa}

Keberhasilan siswa dapat dilihat dari ulangan harian yang diberikan setelah pembelajaran. Dalam penelitian ini diterapkan ketuntasan belajar secara individu dengan ketuntasan belajar 75. Secara klasikal dinyatakan tuntas apabila siswa yang nilainya sudah tuntas mencapai 85\%. Hasil ulangan harian pada siklus 1 dapat dilihat pada Tabel 1.

Tabel 1. Hasil Ulangan Harian Siklus 1

\begin{tabular}{|c|c|c|c|c|c|}
\hline No & $\begin{array}{c}\text { Nilai } \\
\text { tertinggi }\end{array}$ & $\begin{array}{c}\text { Nilai } \\
\text { terendah }\end{array}$ & Rerata & $\begin{array}{c}\text { Siswa yang } \\
\text { belum tuntas } \\
\text { KKM }\end{array}$ & $\begin{array}{c}\% \text { ketun- } \\
\text { tasan klasi- } \\
\text { kal }\end{array}$ \\
\hline 1 & 95 & 60 & 74,8 & 9 & 65,4 \\
\hline
\end{tabular}

Dari data di atas dapat dikatakan bahwa pembelajaran yang dilakukan belum sesuai harapan dan masih terdapat beberapa kekurangan. Berdasarkan observasi, kegiatan pembelajaran masih didominasi oleh siswa tertentu saja. Tingkat pemahaman siswa terhadap materi ajar pada siklus 1 masih belum menunjukkan perubahan yang signifikan dibandingkan sebelum perlakuan. Kenaikan prosentase ketuntasan klasikal dengan sebelum perlakuan hanya $11,6 \%$ saja. Rerata hasil belajar mengalami kenaikan sebesar 7 poin. Hasil ini tentu saja masih belum seperti yang diharapkan, sehingga perlu dilakukan siklus ke 2. Perubahan yang belum menggembirakan ini karena disebabkan guru belum membiasakan menulis bagi siswa yang tidak maju, sehingga siswa menjadi ramai sendiri dalam kelompoknya karena siswa merasa tidak ada kegiatan apapun kecuali hanya mendengarkan siswa yang maju menjawab pertanyaan. Kesiapan siswa untuk mengikuti permainan harus lebih dimotivasi lagi agar semua siswa lebih menguasai lagi materi yang akan dijadikan permainan.

\section{Siklus 2}

\section{Hasil Belajar Siswa}

Perencanaan tindakan yang dilakukan pada siklus 2 merupakan perbaikan rencana tindakan pada siklus 1. Perbaikan dilakukan 
dengan membiasakan siswa untuk membaca dan menulis, memberikan kesempatan lebih banyak pada siswa untuk berperan serta dalam pembelajaran. Beberapa pertanyaan quis dilakukan perbaikan untuk lebih terfokus pada kompetensi dasar tidak mengembang jauh. Guru juga akan mengadakan refleksi dengan siswa setelah pembelajaran, sehingga lebih bermakna.

Ketuntasan belajar pada siklus 2 adalah 75. Secara klasikal dinyatakan tuntas apabila siswa yang nilainya sudah tuntas mencapai 85\%. Hasil ulangan harian pada siklus 2 dapat dilihat pada Tabel 2.

Tabel 2. Hasil Ulangan Harian Siklus 2

\begin{tabular}{|c|c|c|c|c|c|}
\hline No & $\begin{array}{c}\text { Nilai } \\
\text { tertinggi }\end{array}$ & $\begin{array}{c}\text { Nilai } \\
\text { terendah }\end{array}$ & Rerata & $\begin{array}{c}\text { Siswa yang } \\
\text { belum tuntas } \\
\text { KKM }\end{array}$ & $\begin{array}{c}\% \text { ketun- } \\
\text { tasan klasi- } \\
\text { kal }\end{array}$ \\
\hline 1 & 100 & 67 & 82,0 & 3 & 88,5 \\
\hline
\end{tabular}

Dari data di atas dapat dikatakan bahwa pembelajaran yang dilakukan pada siklus 2 sudah mengalami peningkatan sesuai harapan Berdasarkan observasi, siswa sudah mulai mengikuti permainan dengan penuh antusias. Kelas sudah dapat terkondisi dengan baik, karena ada aktifitas menulis bagi siswa yang tidak maju. Siswa sudah menunjukkan keberaniannya untuk berebut maju duduk di kursi panas dan berebut menjawab pertanyaan lemparan. Tingkat pemahaman siswa terhadap materi ajar pada siklus 2 sudah lebih baik dibandingkan dengan siklus 1 . Rerata hasil belajar mengalami kenaikan 8 poin dibandingkan dengan siklus 1 . Kenaikan prosentase ketuntasan klasikal dengan siklus 1 mengalami kenaikan sebesar 19,3\% . Walaupun hasilnya hanya mengalami kenaikan sebesar $19,3 \%$, tetapi hal ini sudah menunjukkan peningkatan yang baik untuk sebuah proses pembelajaran.Perbandingan hasil balajar siswa tiap siklus dapat dilihat pada Tabel 3 berikut :

Tabel 3. Hasil Belajar Siswa

\begin{tabular}{|c|c|c|c|c|}
\hline No & Uraian & Kondisi awal & Siklus 1 & Siklus 2 \\
\hline 1 & Nilai tertinggi & 87 & 95 & 100 \\
2 & Nilai terendah & 50 & 60 & 67
\end{tabular}




\begin{tabular}{|c|cccc|}
3 & $\begin{array}{c}\text { Rerata } \\
4\end{array}$ & 67,8 & 74,8 & 82,0 \\
$\begin{array}{c}\text { Siswa belum } \\
\text { tuntas KKM }\end{array}$ & 12 & 9 & 3 \\
\hline 5 & $\begin{array}{c}\% \text { ketuntasan } \\
\text { klasikal }\end{array}$ & 53,8 & 65,4 & 88,5 \\
\hline
\end{tabular}

Hasil pengamatan dilakukan refleksi antara peneliti dengan observer, disimpulkan bahwa terjadi peningkatan yang signifikan pada siklus 2 dibandingkan dengan siklus 1 . Guru sudah membiasakan siswa menulis dan membaca, sehingga semua siswa ada kegiatan. Hal ini menyebabkan kelas menjadi lebih kondusif.

\section{Aktivitas Siswa}

Aktivitas siswa diamati melalui lembar observasi. Peningkatan aktivitas siswa dapat dilihat dari indikator yang meliputi: keaktifan dalam pembelajaran, interaksi dalam kelompok, interaksi dengan guru, keberanian bertanya dan menjawab pertanyaan serta keceriaan dalam mengikuti pelajaran. Hasil pengamatan aktivitas siswa diberi skor 1 untuk kategori kurang, skor 2 untuk kategori cukup, skor 3 untuk kategori baik dan skor 4 untuk kategori sangat baik. Kriteria penskoran aspek pengamatan adalah nilai $0<$ skor $\leq 20$ kriteria sangat kurang, $20<$ skor $\leq 40$ kriteria kurang baik, $40<$ skor $\leq 60$ kriteria cukup, $60<$ skor $\leq 80$ baik dan $80<$ skor $\leq 100$ kriteria sangat baik. Hasil aktivitas siswa tiap siklus dapat pada Tabel 2. berikut ini:

Tabel 2. keaktifan siswa dalam pembelajaran

\begin{tabular}{|c|c|c|c|}
\hline \multirow{2}{*}{ No } & \multirow{2}{*}{ Aspek yang diamati } & \multicolumn{2}{|c|}{ Kriteria } \\
\hline & & Siklus 1 & Siklus 2 \\
\hline 1 & $\begin{array}{l}\text { Keaktifan siswa dalam mengikuti } \\
\text { pelajaran }\end{array}$ & 3 & 4 \\
\hline 2 & Interaksi siswa dalam kelompok & 3 & 3 \\
\hline 3 & Interaksi siswa dengan guru & 2 & 3 \\
\hline 4 & $\begin{array}{l}\text { Keberanian siswa untuk maju me- } \\
\text { wakili kelompok }\end{array}$ & 3 & 4 \\
\hline
\end{tabular}




\begin{tabular}{|c|l:c:c|}
\hline 5 & $\begin{array}{l}\text { Keberanian siswa menjawab pertan- } \\
\text { yaan }\end{array}$ & 2 & 3 \\
\hline 6 & $\begin{array}{l}\text { Keceriaan siswa dalam mengikuti } \\
\text { pelajaran }\end{array}$ & 3 & 4 \\
\hline 7 & Total nilai & 66,7 & 87,5 \\
\hline
\end{tabular}

Dari hasil pengamatan aktivitas belajar siswa, total nilai pada siklus 1 sebesar 66,7 dengan kriteria baik. Pada siklus 2 aktivitas belajar siswa dengan metode permainan Who Wants To Be A Smart Student mengalami peningkatan menjadi 87,5 dengan kriteria sangat baik.

\section{Pembahasan \\ Siklus 1}

Berdasarkan penelitian terhadap hasil belajar siswa pada kondisi awal dengan siklus 1, terjadi peningkatan ketuntasan belajar minimal. Aktivitas siswa dalam mengikuti pembelajaranpun mengalami peningkatan. Pada kondisi awal, rerata hasil belajar adalah 67,8 dan ketuntasan belajar secara klasikal hanya 57,7 \%. Pada kondisi awal, hanya $40 \%$ siswa yang aktif dalam mengikuti pelajaran. Setelah dilakukan tindakan dengan metode permainan Who Wants to be a Smart Student, pada siklus 1 dengan kompetensi dasar mendeskripsikan sistem koordinasi dan alat indera pada manusia dan hubungannya dengan kesehatan, sub materi sistem koordinasi, terjadi kenaikan prosentase ketuntasan belajar secara klasikal sebesar $11,5 \%$, rerata hasil belajar pada siklus 1 adalah 74,8 berarti mengalami kenaikan sebesar 7 poin dibandingkan kondisi awal. Hasil refleksi antara peneliti dengan observer, kenaikan yang hanya sedikit dikarenakan guru belum membiasakan siswa untuk menulis dan membaca, akibatnya siswa yang tidak maju menjadi ramai sendiri karena merasa tidak dilibatkan secara langsung. Kondisi ini berpengaruh pada kondisi hasil belajar siswa. Aktifitas belajar siswa mengalami kenaikan sebesar $20 \%$.

\section{Siklus 2}

Beberapa kelemahan pada siklus 1, diperbaiki pada siklus 2. 
Pada siklus 2 peneliti masih menggunakan kompetensi dasar yang sama dengan siklus 1 , tetapi sub materi yang berbeda yaitu alat indera manusia. Guru sudah mulai membiasakan siswa yang tidak maju untuk tetap aktif dengan ikut menjawab pertanyaan yang ditayangkan di buku catatan masing-masing dan dikumpulkan setelah selesai pelajaran. Hal ini menyebabkan kelas menjadi lebih kondusif dan semua siswa ikut terlibat, sehingga hasil belaja siswa menjadi meningkat. Hasil belajar siswa menunjukkan bahwa pada siklus 1 prosentase ketuntasan belajar secara klasikal 65,4 \% meningkat menjadi $88,5 \%$ pada siklus 2 . Hal ini berarti ada kenaikan sebesar $23,1 \%$. Rerata hasil belajar pada siklus 2 adalah 82,8 sehingga terjadi kenaikan sebesar 8 poin dari siklus 1 . Aktifitas siswa dalam mengikuti belajar juga mengalami kenaikan yang signifikan yaitu sebesar $85 \%$.

Perbandingan rerata hasil belajar siswa pada kondisi awal, siklus 1 dan siklus 2 dapat dilihat pada grafik 1 .

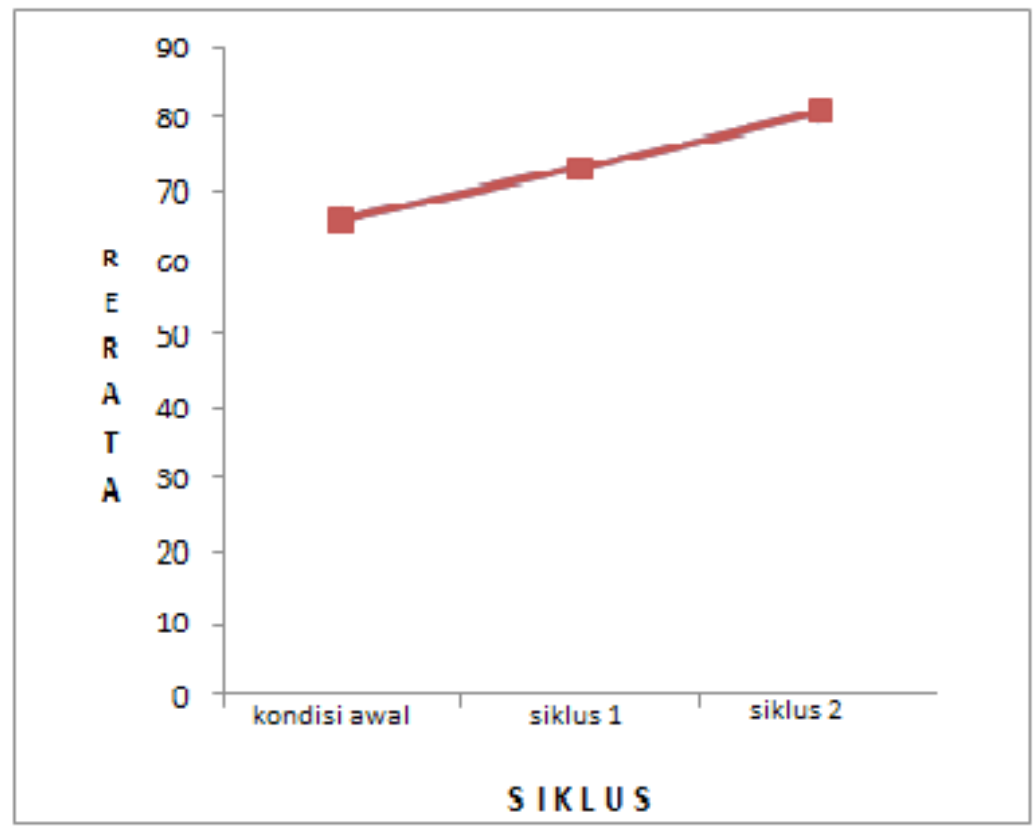

Grafik 1. Perbandingan Rerata Hasil Belajar Siswa 
Perubahan hasil belajar dan aktifitas siswa pada siklus 2 ini disebabkan karena guru sudah mengkondisikan semua siswa untuk ikut terlibat secara langsung dalam pembelajaran. Siswa yang tidak maju ikut menjawab pertanyaan dengan cara menuliskan jawabannya di buku catatan yang nantinya buku tersebut dikumpulkan setelah pelajaran selesai. Perlakuan ini dapat mengaktifkan siswa dalam proses pembelajaran, sehingga akan memacu siswa senantiasa berpikir dan berkomunikasi mulai dari awal sampai akhir pembelajaran. Hal inilah yang dapat meningkatkan pemahaman siswa dalam mempelajari suatu materi, sehingga hasil belajar siswa pun optimal.

Peningkatan hasil belajar dengan metode permainan who wants to be a smart student juga didukung oleh hasil angket siswa yang menyatakan bahwa melalui metode tersebut pelajaran IPA menjadi lebih menarik dan tidak membosankan. Hal ini juga sesuai dengan teori Dominock \& Clark (dalam Hamdani, 2010: 125) yang mengatakan bahwa belajar dengan permainan lebih memungkinkan anak mengembangkan konsep yang didasarkan pada klasifikasi dan mengkontruksi kategori melalui tindakan mereka sendiri.

\section{Aktivitas Siswa}

Aktivitas belajar siswa mengalami kenaikan sebesar $15 \%$ pada siklus 1 dari kondisi awal. Aktifitas siswa dalam mengikuti belajar juga mengalami kenaikan yang signifikan yaitu sebesar 20,5\% pada siklus 2. Kenaikan ini karena guru telah menggunakan metode permainan yang melibatkan siswa secara langsung. Guru sudah mengkondisikan semua siswa untuk ikut terlibat secara langsung dalam pembelajaran. Siswa senantiasa dipacu untuk berpikir dan berkomunikasi mulai dari awal sampai akhir pembelajaran. Hal inilah yang dapat meningkatkan peran aktif siswa dalam pembelajaran. Penelitian ini berakhir pada siklus 2 karena telah mencapai indikator kinerja yang diharapkan.

\section{Simpulan}

Berdasarkan hasil penelitian yang dilakukan di kelas IX F SMP Negeri 1 Bandungan, Kabupaten Semarang tahun pelajaran 
2012/2013 dapat disimpulkan bahwa: (1) Penggunaan metode permainan Who Wants to be A Smart Student membantu siswa dalam meningkatkan hasil belajar siswa; (2) Penggunaan metode permainan Who Wants to be A Smart Student dapat meningkatkan aktivitas belajar siwa.

\section{Saran}

Penggunaan metode permainan Who Wants to be A Smart Student merupakan salah satu metode alternatif bagi guru dalam pembelajaran yang disarankan untuk digunakan pada kompetensi dasar mendeskripsikan sistem koordinasi dan alat indera dan hubungannya dengan kesehatan. 


\section{DAFTAR PUSTAKA}

Barizi, Ahmad dan Muhammah Idris, 2010: Menjadi Guru Unggul, Ar-Ruzz Media: Yogyakarta

Sudibyo, Elok dkk. 2008: Mari Belajar IPA 3, Pusat Perbukuan, Departemen Pendidikan Nasional: Jakarta

Hamdani, M.A, 2011: Strategi Belajar Mengajar, Pustaka Setia: Bandung

Hamruni, M.Si., 2012: Strategi Pembelajaran, Insan Madani: Yogyakarta

Zaini, Hisyam, dkk. 2008: Strategi Pembelajaran Aktif, Pustaka Insan Madani: Yogyakarta

Khoiri, Imam, 2005: Cara Mudah Belajar IPA (Biologi) SMP, Kawan Pustaka: Jakarta

http:/ / www.sekolahdasar.net/2012/05/ pembelajaran-kooperatiftipe-tgt- teams.html\#ixzz2E96gNSw4 diambil 20 maret 2013.

Grafura, Lubis dan Ari Wijayanti. 2012: Metode dan Strategi Pembelajaran yang Unik, Ar-Ruzz Media: Yogyakarta

Silberman, Mel, 2007: Active Learning : 101 Strategi Pembelajaran Aktif, Pustaka Insan Madan: Yogyakarta

Subini, Nini, 2011: Mengatasi Kesulitan Belajar Pada Anak, Javalitera: Yogyakarta

Sumarwan dkk. 2007. IPA SMP untuk Kelas IX, Erlangga: Jakarta Trianto, S.Pd., M.Pd., 2011. Model-Model Pembelajaran Inovatif, Prestasi, Pustaka: Jakarta 